\title{
EAMR
}

European Accounting and

Management Review

EUROPEAN ACCOUNTING AND MANAGEMENT REVIEW · VOL.2, NO.1, 126-138 NOVEMBER 2015

\section{Dynamic capabilities and SME: the example of Chinese tourism companies in Spain}

María del Mar Alonso-Almeida

Universidad Autónoma de Madrid

Krestin Bremser

Pforzheim University of Applied Sciences

Received November 20, 2015; accepted November 26, 2015.

\begin{abstract}
Purpose: The study investigates the strategies of Chinese SME in the tourism sector in Spain to detect if these entrepreneurs employed specific strategies based on the development of dynamic capabilities that could be adopted from other small companies as well. Additionally, the deployment of dynamic capabilities is researched.

Design / Methodology / Approach: The study is exploratory and relies on case studies of three Chinese owned small companies that have been operating from Spain. Cases were chosen to represent different length of investments in Spain, different markets served as well as different ownership structures.
\end{abstract}

Findings: Environmental perceptions play an important role in the development of dynamic capabilities in SME of the tourism sector. New product development and knowledge accumulation are the main capabilities employed.

\section{KEYWORDS}

Dynamic capabilities, tourism, entrepreneurship, financial crisis, Spain. 


\section{Introduction}

Lately, Spain has recovered from a large recession, initiated by the global financial crisis. During crisis situations, tourism industries are especially hard hit since business travel declines and private customers reduce their spending (Okumus et al., 2005). Tourism represents 11.2 per cent of Spanish Gross Domestic Product (Exceltur, 2015) and declines in tourism revenues have strong repercussions in the Spanish economy. Some researchers note that tourism companies suffer more during crisis periods due to a longer recuperation period as well as a large decrease in demand (Okumus et al., 2005, Wang, 2009). Spain was no exception with a decline of revenues of $8.5 \%$ in the tourism sector (between 2008 and 2009) and a slow recuperation. Pre-crisis levels of revenues in the tourism sector were barely reached in 2011 (INE, 2015a).

Research notes that crisis situations are essential for businesses and influence the way capabilities are developed. In addition, uncertainty due to crisis situations influence the way strategies are executed and as a consequence alter performance (Köseoglu et al., 2013). Kim, 1998 provides an early case of Hyundai motor company that uses internal crisis as a way to build up knowledge and develop dynamic capabilities. During turbulent economic times, dynamic capabilities are required to maintain performance (Zhan and Chen, 2013). Firms, disposing of dynamic capabilities and the ability to extract deep knowledge from their stakeholders are able to survive a crisis whereas other companies wither and die (Radway et al., 2011; Alonso-Almeida and Bremser, 2014).

In 2014 Spain had a migrant population of ten percent, with most of the migrants stemming from European or Spanish-speaking countries (INE, 2015 c). The two groups that stand apart are a large Moroccan group (approx. $15 \%$ of Spain's total migrant population) and a smaller Chinese community (approx. $3.5 \%$ of the total migrant population) (INE, $2015 \mathrm{~d}$ ). Whereas the Moroccan community suffered severely from the 2008 economic crisis showing increased unemployment, the receipt of social security benefits and as of 2010 large numbers returning home, the Chinese community showed a different picture with increased employment and smaller numbers returning home (Ma, 2012, INE, 2015c). In addition, the Chinese community shows the largest entrepreneurial spirits among all immigrants to Spain. In 2012, 22 \% of all entrepreneurial work permits granted to foreigners went to Chinese citizens (Ministerio de Empleo y Seguridad Social, 2014). Thus, Chinese entrepreneurs seem to have found a way to avoid the effects of the crisis that hit Spain severely even though they have to muster impediments such as language difficulties, cultural barriers and a contracting economy. 
The current research, exploratory in nature, puts into focus an especially entrepreneurial group of people in order to extend knowledge on dynamic capabilities in small and medium sized enterprises in the hope of enabling other entrepreneurs to follow the Chinese example and also other researchers to benefit from extended knowledge. The reminder of the article is structured as follows: the first part gives a brief overview of the literature, followed by an introduction of the methodology and the presentation of the findings. Afterwards, results are discussed and a conclusion is drawn, pointing out limitations of the study as well as further interesting areas of research.

\section{Review of the literature}

The dynamic capabilities research developed out of the resource-based view introduced by Wernerfelt, 1984. The resource-based view centers on the opinion that companies need four basic preconditions in order to develop competitive advantage. These pillars are superior resources (which are unique in the industry), imperfect resource mobility so that resources stay within one company over a large period of time, ex post and ex ante limits to competition, implying that resources are difficult to substitute or to alter (Peteraf, 1993). This concept was criticized because it failed to explain the success of firms that did dispose of superior resources but were not able to adjust to changes in the competitive environment as for example the US oil industry in the 1980s and 1990s. Thus, Helfat (1997) pointed to the importance of dynamic capabilities that enabled firms to undertake large amount of R\&D activities and build up new sources of income in coal conversion. Teece et al. (1997) also elaborated on the importance of processes that stemmed from the company's resource base and changed a firm's competitive position thereby introducing dynamic aspecst. Later on, researchers built on these ideas and constructed the concept of dynamic capabilities (i.e. Helfat et al., 2010, Teece, 2007, Teece et al., 1997). In the beginning, research centered on large multinational enterprises (e.g. Helfat, 1997), later on, smaller companies came into the focus (e.g. Isobe et al., 2008 or Koubaa, 2014). Large multinational companies dispose of many resources, some of them unique. As Peteraf (1993) states, these resources are superior, with limited mobility and ex ante as well as post limited from competition. This setting is hard to find in a small or mediumsized company (SME). Relying on the resource-based view it remains unclear how some companies thrive in dynamic environments by deploying value-creating strategies even though they do not dispose of special physical resources. Eisenhardt and Martin (2000) 
define dynamic capabilities especially as these processes that enable firms to build upon their resources in order to thrive in all kinds of unstable markets. In this way, firms are able to develop new resources out of their existing ones. Those are no longer limited to just physical assets; they can also be intangible ones. Dynamic capabilities are created out of different sources. Some companies develop them out of lower-order capabilities by extending, modifying or creating ordinary capabilities which in turn enable firms to solve their daily routines and problems (Winter, 2003). Others rely on organizational routines or processes by sensing, seizing and reconfigurating ordinary capabilities (Teece, 2007). An all-encompassing definition of dynamic capabilities can be found at Helfat et al., 2010, p. 4: "A dynamic capability is the capacity of an organization to purposefully create, extend, or modify its resource base." Research has shown that dynamic or crisis environments help companies to build up dynamic capabilities (Newey and Zahra, 2009) In essence, firms developing dynamic capabilities show a very entrepreneurial behavior. Ambrosini et al. (2009) point out the importance of learning to develop dynamic capabilities. They classify dynamic capabilities into a hierarchical order with incremental ones being at the bottom of the hierarchy, slightly modifying existing resources in order to improve performance. As a second step they propose renewing capabilities which secure an income stream in an instable environment. At the top are regenerative dynamic capabilities which can be triggered internally or externally and are used to improve existing capabilities. Regenerative capabilities imply that the organization (or its topmanagers) is able to learn from their mistakes and apply striking changes in order to sustain competitive advantage.

SME dispose of lesser resources than large companies and are often busy organizing their day-to-day business (Alonso-Almeida and Llach, 2013; Alonso-Almeida and Bremser, 2014; Llach and Alonso-Almeida, 2015). Thus, they definitely dispose of operating capabilities. However, some SME overcome the restrictions of their limited resource base and are considered to be innovative, entrepreneurial or simply focused on global instead of local markets and thus also dispose of dynamic capabilities. Especially relying on the explanation of Ambrosini et al. (2009) it becomes obvious that dynamic capabilities need not be restricted to large multinational companies. Since regenerative capabilities can be sourced in from outside by i.e. hiring a new CEO or relying on external expert knowledge, smaller or younger (resource-poor) companies can also benefit from them. Examples are cited among others by Arend, 2014 and Kuuluvainen, 2012. With regard to dynamic capabilities in SME, researchers have often looked on innovation and organizational 
learning and the manufacturing sector. Thus, to broaden the horizon, this research is going to investigate companies from the services industry, namely the sector transport and travelling.

China, as an emerging economy, provides a very different setting to a developed country like Spain. As Guo and Cao (2014) describe, China has an intensely competitive market where firms have to develop constantly new actions and try out new competitive strategies in order to survive. Therefore, it is essential for them to dispose of dynamic capabilities. Moreover, the Chinese community in Spain is a very klose-knit one, with most migrants stemming from just one Chinese county facilitating knowledge and resource transfer. Spain's Chinese migrants rely comparatively less on government support than other parts of the society (Gómez, 2005). Companies that serve China as their main market or were created by founders who have been raised in this environment might still own some of the capabilities and apply them successfully to another market. The last financial crisis was a very volatile environment. Between 2008 and 2011 almost $11 \%$ of companies in the Spanish tourism and transport sector went out of business (INE, 2015b). Those that survived relied on dynamic capabilities as Alonso-Almeida, Bremser and Llach (2015) found out. Therefore, it is of interest to detect the specific capabilities that enabled Chinese entrepreneurs to survive the crisis successfully. Thus, in the following three case studies are analyzed in order to test this issue.

\section{Research Methodology and Research Findings}

Case studies are ideally suited to answer how and why questions (Yin, 2009). The use of case study research is especially appropriate if "how" or "why" questions are studied. Yin (2009) provides the example of the usefulness of even single cases to gain thorough understanding of a phenomenon. Within the dynamic capabilities approach, single cases have been used by Kim, 1998 to point to the importance of crisis for the development of certain capabilities or Kuuluvainen, 2012 to show the existence of dynamic capabilities in small and medium enterprises. Helfat et al. (2010) note that case studies deepen our understanding of the dynamic capabilities approach. They help to understand the dynamics present in a defined setting and the number of cases should be increased until the moment when adding a new case does not apport any additional value to the research in question (Eisenhardt, 1989). 
This research presents an overview of three independent Chinese companies active in the transport and travelling sector in Spain. This sector comprises firms offering transport of goods as well as persons and includes buses and planes. The results are an excerpt of a larger study undertaken during March and April 2015. Companies were asked for their behavior and the strategies employed during the years of the Spanish financial crisis (2008 - 2013) and gave performance indicators. Internet surveys in Chinese language were sent to managers of Chinese companies in Spain. Descriptive data of the companies are shown in table 1.

\begin{tabular}{|c|c|c|c|c|c|}
\hline & Age & Size & Location & $\begin{array}{l}\text { Markets } \\
\text { covered }\end{array}$ & Ownership \\
\hline Company A & $<5$ years & $<50$ employees & Spain & China & Female \\
\hline Company B & $\begin{array}{c}11-25 \\
\text { years }\end{array}$ & $<50$ employees & Madrid & $\begin{array}{c}\text { China and } \\
\text { Europe }\end{array}$ & Family \\
\hline Company $\mathrm{C}$ & $\begin{array}{l}>25 \\
\text { years }\end{array}$ & $<50$ employees & Madrid & $\begin{array}{c}\text { China and } \\
\text { Europe }\end{array}$ & Male \\
\hline
\end{tabular}

Table 1. Descriptive Data of the Companies

According to literature, company A should not dispose of dynamic capabilities because it is still too young. Dynamic capabilities need time to build up (cf. the lifecycle of dynamic capabilities by Helfat and Peteraf, 2003).

Given its focus on the Chinese market, company A judges its industry (despite of the crisis in Spain) as a rather stable one. Neither marketing strategies nor product offerings have to be changed because of competitive actions. In addition, the views of customers are predictable. Competitors are not as predictable but do not pose severe problems. The owners were aware of the past crisis in Spain and had in general been prepared for it. A plan with anti-crisis measures existed. Despite its young age, the founder had already experienced other critical situations beforehand and adjusted accordingly. The female owner of the company considers herself to be a risk-taker, pursuing a "good quality has its price" strategy. The financial crisis strengthened the company and it is now having slightly higher sales, profits and market share than its competition. This may result out of the fact that the main competition is located in China. Despite its limited financial resources, young age and average supply of resources as well as white and blue collar workers it proves to be constantly innovating. The company changes its marketing efforts and the way that services are offered on a regular base (i.e. more than once a year) in 
order to stay ahead of the competition. Accordingly, the company believes that its ability to accumulate new knowledge as well as the ability to assign and utilize resources improved considerably. In addition it is very positive about other factors indicating the existence of dynamic capabilities, for instance the efficiency in knowledge accumulation or new product development. Summing it up, the company seems to be able to develop dynamic marketing capabilities because of its high innovation focus.

Company B considers itself to be working in a very stable environment where customers and competitors are easily to predict and marketing activities or product offerings change seldom. It pursues a quality leader strategy. However, its outlook for the industry is gloomy and the family owners believe the environment to be a very hostile one where it is difficult to survive. This is due to the fact that resources (capital, blue and white collar labor and supplies) are very costly. Despite its age, the company has never lived through such a deep crisis before and hence had not been able to learn from past experiences or develop an anti-crisis. Still, given the high rate of bankruptcy in Spain, it was still able to come out of the crisis relatively strong. Given its belief in a stable industry and its riskaversity, the family has not changed operating routines over the five years of the crisis and stuck to the same procedures. The owners believe that the company came out of the crisis weakened and are rather negative about factors indicating dynamic capabilities as i.e. knowledge accumulation and distribution or resource allocation. Moreover the family believes that the company is faring slightly worse than its competition. As a result, the family relied on proven routines and neither developed nor used dynamic capabilities during the crisis.

Company $\mathrm{C}$ judges its industry as a rather volatile one. Marketing activities, product offerings have to be changed very often and the actions of the competition are not easily predicted. Moreover, customer demands are not easily foreseen, thus, complicating successful business even further. The male owner of the company considers himself to be a risk-taker pursuing a "good quality has its price" strategy. The financial crisis was difficult for the company but it managed to fare slightly better than its competition. Given its long standing in the sector it had already experienced other critical situations before and learned from them. Thus, it was able to strengthen its competitive position. Similar to company A it is changing its resource base on a regular base albeit on a slower pace (approximately yearly) in order to stay ahead of the competition. Contrary to company A it focuses its effort only on the way services are produced. Still, the owner is rather positive in his attitudes towards factors that permit the development of dynamic 
capabilities, for instance new product development, knowledge accumulation and new learning methods. In sum, the company seems to have developed some dynamic capabilities.

A summary of findings are presented in table 2 .

\begin{tabular}{|c|c|c|}
\hline Company A & Company B & Company C \\
\hline $\begin{array}{l}\text { Environment perception: } \\
\text { Little changed }\end{array}$ & $\begin{array}{l}\text { Environment perception: } \\
\text { Stable }\end{array}$ & $\begin{array}{l}\text { Environment perception: } \\
\text { Volatile }\end{array}$ \\
\hline $\begin{array}{l}\text { Dynamic Capabilities } \\
\text { deployed: } \\
\text { - Accumulated new } \\
\text { knowledge. }\end{array}$ & $\begin{array}{l}\text { Dynamic Capabilities } \\
\text { deployed: } \\
\text { - No changed operations } \\
\text { for five years. No dynamic } \\
\text { capabilities deployed. }\end{array}$ & $\begin{array}{l}\text { Dynamic Capabilities } \\
\text { deployed: } \\
\text { - Accumulated new } \\
\text { knowledge. } \\
\text { - Continuous learning }\end{array}$ \\
\hline $\begin{array}{l}\text { Results: } \\
\text { Improved usage of } \\
\text { resources and processes. }\end{array}$ & $\begin{array}{l}\text { Results: } \\
\text { None. }\end{array}$ & $\begin{array}{l}\text { Results: } \\
\text { Developed new products. }\end{array}$ \\
\hline
\end{tabular}

Table 2. Summary of findings 


\section{Discussion of results and conclusions}

Thus, as can be seen in table 2 different findings have been identified.

First, managerial perceptions of the environment are confirmed to trigger the deployment of dynamic capabilities (Ambrosini et al., 2009). The findings show that both company A and company $\mathrm{C}$ dispose of dynamic capabilities. Ambrosini et al. (2009) point out that the deployment of dynamic capability depends a lot on managerial perceptions. Managers that perceive their environment to be a stable one will not implement changes to their resource base in order to improve competitiveness. Company B provides an example of this sort of behavior. Despite the perceptions of the two other companies working in a very similar environment and macroeconomic indicators pointing to a very critical time period for businesses operating in Spain, it does not perceive its environment to be volatile.

Second, companies who consider that environment changes (little or much) identify the need to adapt to the changing environment and show a similar behavior in terms of dynamic capabilities adoption. Thus, knowledge accumulation and its use in new ways seems to be the main dynamic capability deployed. However, on the one hand companies used the knowledge accumulated over the time (company $\mathrm{C}$, older company) to face changes in environment and to create new products. On the other hand, some companies (company A, youngest company) use this new knowledge to improve resources and processes.

Third, the type of ownership emerges to be another driver to determine the deployment of dynamic capabilities. Nevertheless, more research should be conducted in this area.

Finally, unfortunately, the results do not indicate that the Chinese entrepreneurs deployed strikingly different strategies or undertook special actions compared to other companies basing their operations in Spain. As already stated in previous research on the Spanish tourism sector, they relied on innovation and marketing efforts in order to overcome the crisis years (Alonso-Almeida and Bremser, 2013)

Concluding, it can be said that small companies working in a foreign environment are able to make use of dynamic capabilities. However, in the case of the surveyed companies it requires an entrepreneurial mind with a certain readiness to accept risks.

Obviously, the research has some limitations with regards to geographical and industry coverage. The small sample size does not permit to generalize the results and can only give indications. Therefore, repeating the research with a larger sample of companies would be very useful. In addition, it could be of interest to study cultural aspects or work 
with matching pairs of Spanish and Chinese enterprises in order to detect more differences between Chinese and Spanish SME. 


\section{REFERENCES}

Alonso-Almeida, M.M., Bremser, K., \& Llach, J. (2015), "Proactive and Reactive Strategies deployed by restaurants in times of crisis: effects on capabilities, organization and competitive advantage", International Journal of Contemporary Hospitality Management, 27 (7), pp. 1641-1661.

Alonso-Almeida, M. M., Bremser, K. (2014), "Strategic management decisions in power positions to achieve business excellence in small service businesses: does gender matter?", European Accounting and Management Review, Vol. 1, Issue 1, 2014.

Available at SSRN:http://ssrn.com/abstract $=2532404$

Alonso-Almeida, M.M. and Bremser, K. (2013), "Strategic responses of the Spanish hospitality sector to the financial crisis", International Journal of Hospitality Management, 32, pp. 141-148.

Alonso-Almeida, M.M.; Llach, J. (2013), "Adoption and use of ICTS in small business environments: impact on business competitiveness", The Service Industries Journal, 33, No. 15-16, pp. 1476-1492.

Ambrosini, V., Bowman, C. and Collier, N. (2009), "Dynamic Capabilities: An Exploration of How Firms Renew their Resource Base", British Journal of Management, 20, pp. S9.

Arend, R. J. (2014), “Entrepreneurship and dynamic capabilities: how firm age and size affect the 'capability enhancement-SME performance' relationship", Small Business Economics, 42(1), 33-57, http://dx.doi.org/10.1007/s11187-012-9461-9.

Eisenhardt, K. M. (1989), "Building Theories from Case Study Research", Academy of Management Review, 14 (4), 532-550.

Eisenhardt, K.M. and Martin, J.A. (2000), "Dynamic capabilities: what are they?", Strategic Management Journal, 21, pp. 1105-1121.

Exceltur (2015), PIB turístico español 2015, http://www.exceltur.org/indice-sinteticodel-pib-turistico-espanol-iste, accessed october, 28, 2015.

Gómez, L. (2005), "El poder chino en España”, El País, 27.03.2005, http://elpais.com/diario/2005/03/27/domingo/1111898492_850215.html, retrieved October, 26th, 2015.

Guo, H. and Cao, Z. (2014), "Strategic flexibility and SME performance in an emerging economy”, Journal of Organizational Change Management, 27 (2), pp. 273-298.

Helfat, C. E. (1997), "Know-how and asset complementarity and dynamic capability accumulation: the case of R\&D”, Strategic Management Journal, 18, 339-360.

Helfat, C. E., Finkelstein, S., Mitchell, W., Peteraf, M. A., Singh, H., Teece, D. J., \& Winter, S. G. (2010), Dynamic capabilities: Understanding strategic change in organizations, Malden, MA [u.a.]: Blackwell Publ. 
Helfat, C. E., \& Peteraf, M. A. (2003), "The dynamic resource-based view: capability lifecycles", Strategic Management Journal, 24(10), 997-1010.

INE (2015 a), “Cuenta satélite del turismo de España. Base 2008. Serie contable 20082012",

http://www.ine.es/jaxi/menu.do?type=pcaxis\&path=/t35/p011/2012/\&file=pcaxis, retrieved May 19th, 2015.

INE (2015 b), "Encuesta Anual de Servicios (CNAE-2009). Año 2008", http://www.ine.es/jaxi/menu.do?type $=$ pcaxis\&path $=\% 2 \mathrm{Ft} 37 \% 2 \mathrm{Fe} 01 \&$ file $=$ inebase $\& \mathrm{~L}=$ 0, retrieved May, 19th, 2015.

INE (2015 c), "Saldo migratorio con el extranjero por año, sexo, grupo de edad y nacionalidad",

http://www.ine.es/jaxi/tabla.do?path=/t20/p277/prov/e01/10/\&file=01013.px\&type=pca xis $\& L=0$, retrieved October 22,2015.

INE (2015 d), "Notas de Prensa, Estadística de Migraciones 2014", http://www.ine.es/prensa/np917.pdf, retrieved October 22,2015.

Isobe, T., Makino, S., \& Montgomery, D. B. (2008), “Technological capabilities and firm performance: The case of small manufacturing firms in Japan", Asia Pacific Journal of Management, 25(3), 413-428.

Kim, L. (1998), “Crisis Construction and Organizational Learning: Capability Building in Catching-up at Hyundai Motor", Organization Science, 9(4), 506-521.

Koubaa, S. (2014), "Management stratégique des connaissances et capacité d'absorption dans le contexte des relations interentreprises", Revue des Sciences de Gestion, 49(266), 109-120.

Köseoglu, M.A., Topaloglu, C., Parnell, J.A. and Lester, D.L. (2013), "Linkages among business strategy, uncertainty and performance in the hospitality industry: Evidence from an emerging economy", International Journal of Hospitality Management, 34 (1), pp. $81-91$.

Kuuluvainen, A. (2012). How to concretize dynamic capabilities? Theory and examples. Journal of Strategy and Management, 5(4), 381-392.

Llach, J., Alonso-Almeida, M. M. (2015), "Integrating ICTS and supply chain management: the case of micro-sized firms", Human Factors and Ergonomics in Manufacturing \& Service Industries, 25, No. 4, pp. 385-397.

Ma, S. (2012), "For Spain, an Economic Lifeline From China”, Business Week, 4268, pp. $17-18$.

Ministerio de Empleo y Seguridad Social (2014), Estadística de autorizaciones de trabajo a extranjeros año 2012, http://www.empleo.gob.es/estadisticas/pte/pte12/ANE/PTEp.htm, retrieved October 22,2015 . 
Newey, L.R. and Zahra, S.A. (2009), "The Evolving Firm: How Dynamic and Operating Capabilities Interact to Enable Entrepreneurship", British Journal of Management, 20, pp. $81-100$

Okumus, F., Altinay, M., \& Arasli, H. (2005), "The impact of Turkey's economic crisis of February 2001 on the tourism industry in Northern Cyprus", Tourism Management, 26, 95-104, doi:10.1016/j.tourman.2003.08.13.

Peteraf, M.A. (1993), "The cornerstone of competitive advantage: A resource based view”, Strategic Management Journal, 14 (3), pp. 179 - 191.

Radway, R., Helmersson, A. and Melander, A. (2011), "Facing the global economic crisis: the case of Swedish heavy vehicle subcontractors", International Journal of Automotive Technology \& Management, 11 (3), pp. 269-293.

Teece, D. J. (2007), "Explicating dynamic capabilities: the nature and microfoundations of (sustainable) enterprise performance", Strategic Management Journal, 28(13), 13191350 .

Teece, D. J., Pisano, G., \& Shuen, A. (1997), "Dynamic capabilities and strategic management”, Strategic Management Journal, 18(7), 509-533.

Wang, Y.S. (2009), "The impact of crisis events and macroeconomic activity on taiwan's international inbound tourism demand", Tourism Management, 30, pp. 75-82.

Wernerfelt, B. (1984), "A resource-based view of the firm", Strategic Management Journal, 5 (2), 171-180.

Winter, S.G. (2003), "Understanding Dynamic Capabilities", Strategic Management Journal, 24, pp. 991-995.

Yin, R. K. (2009), Case study research: design and methods (4th ed.). Los Angeles, Calif.: Sage.

Zhan, W. and Chen, R. (2013), "Dynamic capability and IJV performance: The effect of exploitation and exploration capabilities", Asia Pacific Journal of Management, 30, 601632. 